\title{
CONSERVAÇÃO DE MELÃO RENDILHADO MINIMAMENTE PROCESSADO SOB ATMOSFERA MODIFICADA ATIVA ${ }^{1}$
}

\author{
Maria Cecília de ARRUDA ${ }^{2 * *}$, Angelo Pedro JACOMINO,
}

Marta Helena Fillet SPOTO ${ }^{4}$, Cláudio Rosa GALLO ${ }^{5}$, Celso Luiz MORETTI ${ }^{6}$

\begin{abstract}
RESUMO
Melões rendilhados cv. Bônus II foram minimamente processados manualmente na forma de cubos, acondicionados em diversos materiais de embalagem com injeção da mistura gasosa $\left(5 \% \mathrm{O}_{2}+20 \% \mathrm{CO}_{2}+75 \% \mathrm{~N}_{2}\right)$ e armazenados a $3^{\circ} \mathrm{C}$ durante 12 dias. Os materiais de embalagem foram: BB-200: filme multicamada da Cryovac $65 \mu \mathrm{m}$; PBC:filme poliolefínico Probag Conservax 64 $\mu \mathrm{m}$; PP: filme de polipropileno $52 \mu \mathrm{m}$. Como controle, utilizou-se bandeja de polietileno com tampa perfurada. Realizou-se monitoramento da composição gasosa, análises microbiológicas, sensoriais e físico-químicas a cada 3 dias. Foram determinadas as taxas de permeabilidade ao $\mathrm{O}_{2}$ e $\mathrm{CO}_{2}$ de cada filme. A embalagem BB-200 promoveu acúmulo de $\mathrm{CO}_{2}$ até níveis de $24 \%$ e redução de $\mathrm{O}_{2}$ até níveis de $0,4 \%$. Na embalagem PBC a concentração de $\mathrm{O}_{2}$ estabilizou-se ao redor de $8 \%$ e a de $\mathrm{CO}_{2}$ ao redor de $4 \%$, enquanto na embalagem de PP os níveis de gases estabilizaram-se ao redor de $13 \% \mathrm{O}_{2}$ e $6 \% \mathrm{CO}_{2}$. De maneira geral, as características físico-químicas e sensoriais foram pouco influenciadas pelos tratamentos. A alteração da composição gasosa foi eficiente no controle de microrganismos. A partir do $9^{\circ}$ dia de armazenamento, os melões controle apresentaram niveis de bactérias mesófilas acima de $10^{5} \mathrm{NMP} / \mathrm{g}$, com riscos de apresentarem microrganismos patogênicos e/ou deterioradores.

Palavras-chave: Cucumis melo L.; embalagem; processamento mínimo; armazenamento refrigerado; mistura gasosa; microbiologia.
\end{abstract}

\section{SUMMARY}

CONSERVATION OF MINIMALLY PROCESSED NET MELON UNDER ACTIVE MODIFIED ATMOSPHERE. Net melons cv. Bonus II were minimally processed as cubes, wrapped in several packaging materials with injection of the gaseous mixture $\left(5 \% \mathrm{O}_{2}+20 \% \mathrm{CO}_{2}+75 \%\right.$ $\mathrm{N}_{2}$ ) and stored at $3^{\circ} \mathrm{C}$ for 12 days. The packaging materials were: BB-200: Cryovac multlayer film 65 $\mu$ m; PBC: Probag Conservax polyolephinic film $64 \mu \mathrm{m}$; PP: polypropylene film $52 \mu \mathrm{m}$. Polystyrene trays were used as control with perforated cover. Gaseous composition inside of the packaging, microbiological, sensorial and physical-chemical characteristics were determined each 3 days. The gas permeability was determined for each film. BB-200 packaging promoted $\mathrm{CO}_{2}$ accumulation until $24 \%$ and $\mathrm{O}_{2}$ reduction until $0,4 \%$. Inside PBC packaging the $\mathrm{O}_{2}$ concentration stabilized at $8 \%$ and $\mathrm{CO}_{2}$ about $4 \%$, while inside PP packaging the gaseous concentration stabilized near $13 \%$ for $\mathrm{O}_{2}$ and $6 \%$ for $\mathrm{CO}_{2}$. In a general sense, physical-chemical and sensorial characteristics were not influenced by the treatments. The modified atmosphere packaging was efficient for the microorganism control. The melon without modified atmosphere packaging showed levels over $10^{5} \mathrm{NMP} / \mathrm{g}$, of mesophilics bacteria, wich pathogenic microorganisms risks and/or deteriorative microorganisms, after $9^{\text {th }}$ storage day.

Keywords: Cucumis melo L.; packing; fresh-cut; cold storage; gaseous mixture; microbiology.

\section{1 - INTRODUÇÃo}

O processamento mínimo usualmente descreve um produto fresco, adequadamente descascado, fatiado ou cortado, 100\% comestivel, contrastando às técnicas de processamento convencionais que incluem congelamento, enlatamento, secagem, etc. [4].

A mudança nos padrões de consumo de alimentos tem levado ao maior consumo de frutas e hortaliças em detrimento dos produtos industrializados. Ao mesmo tempo, os consumidores desejam produtos com qualidade e praticidade. Nesse sentido, a demanda por frutas e hortaliças minimamente processadas tem evoluído rapidamente [6, 13].

\footnotetext{
1. Recebido para publicação em 01/08/2002. Aceito para publicação em 23/10/2003 (000925).

2. ESALQ/USP, Departamento de Produção Vegetal. Caixa Postal 09, CEP 13418-900, Piracicaba. E-mail: mcarruda@esalq.usp.br.

3. ESALQ/USP, Departamento de Produção Vegetal. E-mail: jacomino@esalq.usp.br.

4. ESALQ/USP, Departamento de Agroindústria, Alimentos e Nutrição. E-mail: mhfspoto@esalq.usp.br.

5. ESALQ/USP, Departamento de Agroindústria, Alimentos e Nutrição.

E-mail: crgallo@esalq.usp.br.

6. EMBRAPA Hortaliças, Brasília-DF. E-mail: celso@cnph.embrapa.br.

*A quem a correspondência deve ser enviada.
}

Um dos maiores problemas dos produtos minimamente processados é sua rápida deterioração. As injúrias provocadas no tecido, por ocasião do corte, elevam a taxa respiratória e a produção de etileno. O etileno contribui para a biossintese de enzimas envolvidas em mudanças fisiológicas e bioquímicas. [5]. De acordo com MATHOOKO [10], níveis elevados de $\mathrm{CO}_{2}$ inibem a síntese de etileno, o que indica que este tratamento pode ser utilizado para conservação de produtos hortícolas minimamente processados.

A modificação da atmosfera em uma embalagem plástica pode ser estabelecida de forma passiva ou ativa. A atmosfera modificada passiva se estabelece pela própria respiração do produto e a permeabilidade do material de embalagem, enquanto em atmosfera modificada ativa é feita uma injeção de gases na embalagem, no momento em que o produto é embalado [9].

Em produtos onde o consumo de $\mathrm{O}_{2}$ é baixo e a atmosfera modificada se estabelece lentamente, as reações bioquímicas podem causar deterioração no produto antes que ocorra o equilíbrio dos gases [14].

Sendo assim, a principal vantagem da atmosfera modificada ativa está na rapidez com que a atmosfera desejada é estabelecida. O objetivo deste trabalho foi avaliar os efeitos de materiais de embalagem, associa- 
dos a atmosfera modificada ativa na manutenção da qualidade de melões minimamente processados.

\section{2 - MATERIAL E MÉTODOS}

\section{1 - Obtenção dos melões}

Melões rendilhados cv. Bônus II produzidos no Rio Grande do Norte foram selecionados, acondicionados em caixas de papelão e transportados em caminhão refrigerado até o CEASA-Campinas, onde foram adquiridos e levados ao Laboratório de Pós-Colheita do Departamento de Produção Vegetal da ESALQ/USP. Foram lavados com detergente a fim de retirar as sujidades mais grosseiras, sendo em seguida imersos em solução de hipoclorito de sódio a 100ppm por 10 minutos para evitar contaminação durante o processamento. Terminada esta etapa, os melões foram pré-resfriados em câmara fria a $10^{\circ} \mathrm{C}$ por 12 horas.

\section{2 - Processamento}

Os melões refrigerados foram processados em câmara fria a $12^{\circ} \mathrm{C}$ sobre mesa inox, devidamente higienizada. Os operadores utilizaram botas, aventais, luvas, máscaras e toucas, como parte das condições mínimas de assepsia.

As etapas do processamento constaram de: a) Corte: os melões foram cortados manualmente ao meio e as sementes retiradas com auxílio de uma colher. Cada metade foi cortada em 4 fatias longitudinais que tiveram a casca eliminada. As fatias foram divididas em cubos de aproximadamente $3 \mathrm{~cm}$ de base; b) Desinfecção: os pedaços foram imersos em solução de hipoclorito de sódio a 100ppm por 3 segundos, com objetivo de reduzir riscos de contaminação; c) Eliminação do excesso de água: os pedaços de melões foram drenados por aproximadamente 1 minuto em escorredor doméstico, devidamente higienizado; d) Embalagem: após a retirada do excesso de água, os pedaços de melão foram colocados em bandejas de polietileno rígida sem tampa, com capacidade de $750 \mathrm{~mL}$, as quais foram colocadas em sacos plásticos constituídos de diferentes filmes. A selagem foi efetuada em seladora à vácuo Selovac. Efetuou-se evacuação do ar do interior da embalagem e injeção da mistura gasosa. Como controle utilizou-se bandeja de polietileno rígida com tampa perfurada para evitar a modificação da atmosfera em seu interior. Os materiais de embalagem (filmes plásticos) utilizados foram: BB-200: filme multicamada da Cryovac $65 \mu \mathrm{m}$; PBC: filme poliolefínico Probag Conservax $64 \mu \mathrm{m}$; PP: filme de polipropileno $52 \mu \mathrm{m}$.

Ao final do processo de embalagem, o produto foi armazenado em câmara fria a $3^{\circ} \mathrm{C}$ por 12 dias. A cada 3 dias foram realizadas análises físico-químicas, sensoriais e microbiológicas e monitoramento da composição gasosa do espaço livre das embalagens.

O delineamento experimental foi inteiramente casualizado com 4 tratamentos e 5 repetições, sendo cada repetição representada por uma bandeja contendo aproximadamente $240 \mathrm{~g}$ do produto minimamente processado. Os resultados foram submetidos à análise de variância pelo teste $\mathrm{F}$ e comparação de médias pelo teste de Tukey (5\%).

\section{3 - Descrição das análises}

\subsection{1 - Caracterização dos materiais de embala- gem}

A taxa de permeabilidade ao $\mathrm{O}_{2}$ e ao $\mathrm{CO}_{2}$ foi determinada por método de aumento da concentração, segundo procedimento descrito por OLIVEIRA et al. [11].

Foram utilizadas células de difusão de gás constituídas por 2 câmaras. Na câmara superior foi mantido um fluxo de gás permeante, que ao permear o corpo de prova acumulou-se na câmara inferior, fechada para atmosfera. Em intervalos pré-determinados foram retiradas alíquotas de $300 \mu \mathrm{L}$ de gás, desta câmara, para quantificação do gás permeante em cromatógrafo a gás marca Shimadzu, modelo 14A. Os resultados de cromatografia foram analisados por um integrador, com base em curva padrão feita com gás de calibração.

A área de permeação efetiva das embalagens foi determinada pelo produto das dimensões entre as linhas de selagem das embalagens. Foram medidas todas as embalagens de cada tratamento e calculadas as médias aritméticas.

\subsection{2 - Monitoramento da composição gasosa}

Para o monitoramento da composição gasosa foi fixado em cada embalagem um septo de silicone através do qual foram coletadas amostras de gás do interior das embalagens utilizando-se um analisador de gases marca PBI-Dansensor, modelo Check Mate, o qual retira aproximadamente $2 \mathrm{~mL}$ de gás por amostra. As leituras foram realizadas a cada 3 dias e os resultados foram expressos em $\% \mathrm{O}_{2}$ e $\% \mathrm{CO}_{2}$.

\subsection{3 - Análise microbiológica}

A análise microbiológica foi realizada pela metodologia Simplate ${ }^{T M}$, determinando-se a contagem de bactérias aeróbias mesófilas e presença de coliformes. O princípio deste método baseia-se na tecnologia do substrato enzimático, correlacionando a atividade enzimática com a presença de microrganismos viáveis no alimento. O kit, fabricado pela Idexx Laboratories Inc consta de meio de cultura desidratado e placas descartáveis com 84 cavidades.

\subsection{4 - Análise Sensorial}

Foi realizada no Laboratório de Análise Sensorial do Departamento de Agroindústria, Alimentos e Nutrição, ESALQ/USP. Os provadores avaliaram as amostras em cabines individualizadas. Cada provador recebeu $30 \mathrm{~g}$ de produto por amostra devidamente codificada, juntamente com a ficha de avaliação e água para lavagem da boca entre as avaliações. 
Os provadores avaliaram primeiro o aroma e o sabor do produto em cabines com lâmpadas vermelhas para mascarar a cor. Posteriormente, avaliaram a aparência em cabine dotada de lâmpada fluorescente. As amostras de aparência continham aproximadamente 200 g de melão.

As avaliações foram realizadas por uma equipe de 17 provadores não treinados, utilizando-se escala hedônica de 9 pontos, variando de 9 (gostei extremamente) a 1 (desgostei extremamente) [12].

\subsection{5 - Análises físico-químicas}

a) Escurecimento: determinado com colorímetro Minolta, modelo CR-300, tomando-se leitura na região placentária do cubo. As leituras foram realizadas em 6 cubos por repetição e os resultados expressos em Luminosidade (L*).

b) Firmeza da polpa: determinada com penetrômetro digital, ponteira $8 \mathrm{~mm}$, tomando-se uma leitura na região placentária do cubo. As leituras foram realizadas em 6 cubos por repetição e os resultados expressos em Newton (N).

c) Teor de Sólidos Solúveis Totais (SST): leitura direta em refratômetro digital Atago modelo Palete 101 , utilizando-se polpa homogeneizada em triturador doméstico tipo "mixer". Os resultados foram expressos em ${ }^{\circ}$ Brix.

d) $\mathrm{pH}$ : leitura em solução de polpa homogeneizada, com pHmetro marca Tecnal.

e) Acidez titulável: determinada por titulometria com $\mathrm{NaOH} 0,1 \mathrm{~N}$. Os resultados foram expressos em \% de ácido málico.

f) Teor de ácido ascórbico: determinado de acordo com metodologia descrita por CARVALHO, MANTOVANI \& CARVALHO [7]. Os resultados foram expressos em mg de ácido ascórbico/100g de polpa.

\section{3 - RESULTADOS E DISCUSSÃO}

\section{1 - Composição gasosa no espaço livre das emba- lagens}

Na Figura 1 observa-se alta eficiência na modificação ativa da atmosfera na embalagem, ou seja, o ar ambiente do interior das embalagens foi totalmente substituído pela mistura gasosa de $5 \% \mathrm{O}_{2}+20 \% \mathrm{CO}_{2}+75 \% \mathrm{~N}_{2}$. Analisando a evolução da composição gasosa do interior das embalagens, verifica-se que o filme BB-200 promoveu acúmulo de $\mathrm{CO}_{2}$ e redução de $\mathrm{O}_{2}$ do interior da embalagem ao longo do armazenamento, atingindo níveis de $24 \% \mathrm{CO}_{2}$ e $0,4 \% \mathrm{O}_{2}$. Embora a taxa respiratória do melão seja bastante baixa este comportamento era esperado, devido a baixa taxa de permeabilidade deste filme aos gases $\mathrm{O}_{2}$ e $\mathrm{CO}_{2}$ (Tabela 1).

Os filmes PBC e PP permitiram a gradativa saída de $\mathrm{CO}_{2}$ e entrada de $\mathrm{O}_{2}$ nas embalagens ao longo do armazenamento. A composição gasosa nestas embalagens ao final de 12 dias foi de aproximadamente $4 \% \mathrm{CO}_{2} \mathrm{e}$
$8 \% \mathrm{O}_{2}$ no filme PBC e $6 \% \mathrm{CO}_{2}$ e $13 \% \mathrm{O}_{2}$ no filme PP. Portanto, a atmosfera manteve-se com maior modificação no filme BB-200, seguido pelo $\mathrm{PBC}$ e por último o PP. Este comportamento dos filmes é compativel com a taxa de permeabilidade dos mesmos que segue a ordem inversa da modificação da atmosfera (Tabela 1), ou seja, os filmes mais permeáveis permitiram maior perda da atmosfera introduzida no interior da embalagem.

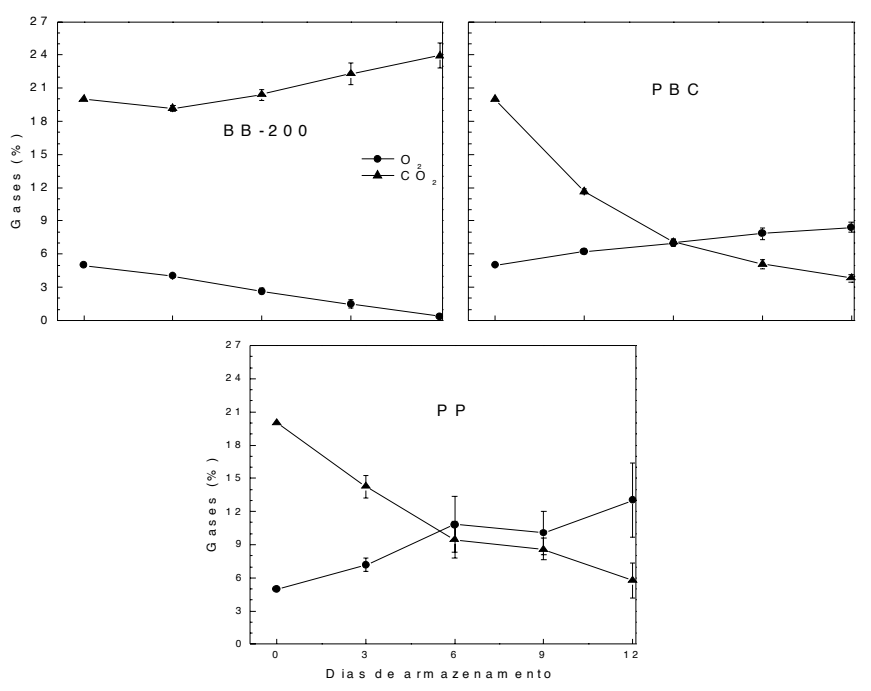

FIGURA 1. Evolução da composição gasosa no espaço livre das embalagens contendo melões rendilhados minimamente processados armazenados a $3^{\circ} \mathrm{C}$, sendo: $\mathrm{BB}-200$ : filme multicamada da Cryovac $65 \mu \mathrm{m}$; PBC: filme poliolefínico Probag Conservax $64 \mu \mathrm{m}$; PP: filme de polipropileno $52 \mu \mathrm{m}$.

TABELA 1. Características dos materiais de embalagem empregados no acondicionamento de melões rendilhados minimamente processados

$\begin{array}{cccc}\text { Embalagens } & \begin{array}{c}\text { Espessura } \\ (\mu \mathrm{m})\end{array} & \begin{array}{c}\mathrm{TPO}_{2} \\ \left(\mathrm{~cm}^{3} \mathrm{~m}^{-2} \cdot \mathrm{dia}^{-1}\right)\end{array} & \begin{array}{c}\mathrm{TPCO}_{2} \\ \left(\mathrm{~cm}^{3} \cdot \mathrm{m}^{-2} \cdot \mathrm{dia}^{-1}\right)\end{array} \\ \mathrm{BB}^{-200} 0^{1} & 65 & 9 & 25 \\ \mathrm{PBC}^{2} & 64 & 1.005 & 7.991 \\ \mathrm{PP}^{3} & 52 & 1.961 & 6.821\end{array}$

${ }^{1}$ filme multicamada da Cryovac $65 \mu \mathrm{m} ;{ }^{2}$ filme poliolefinico Probag Conservax $64 \mu \mathrm{m}$; ${ }^{3}$ filme de polipropileno $52 \mu \mathrm{m}$.

TABELA 2. Características das embalagens empregadas no acondicionamento de melões rendilhados minimamente processados

$\begin{array}{cccc}\text { Embalagens } & \begin{array}{c}\text { Área efetiva de } \\ \text { permeação }\end{array}{ }^{\mathrm{A}}\left(\mathrm{cm}^{2}\right) & \begin{array}{c}\text { Massa de melão } \\ (\mathrm{g})\end{array} & \text { Relação A/B }\left(\mathrm{cm}^{2} / \mathrm{g}\right) \\ \mathrm{BB}^{\mathrm{B}}-200^{1} & 892 & 240 & 3,72 \\ \mathrm{PBC}^{2} & 858 & 240 & 3,58 \\ \mathrm{PP}^{3} & 880 & 240 & 3,67\end{array}$

${ }^{1}$ filme multicamada da Cryovac $65 \mu \mathrm{m} ;{ }^{2}$ filme poliolefínico Probag Conservax $64 \mu \mathrm{m}$ ${ }^{3}$ filme de polipropileno $52 \mu \mathrm{m}$.

As diferenças de composição gasosa no interior das embalagens são devidas às características de permeabilidade dos filmes, uma vez que a relação entre a área de permeação e a massa de melão (Tabela 2) foi muito semelhante nos três tratamentos. 


\section{2 - Análise microbiana}

Pelas Tabelas 3 e 4 observa-se que os melões controle apresentaram durante o periodo de armazenamento as maiores contagens totais de bactérias aeróbias mesófilas e também de bactérias do grupo coliformes totais.

TABELA 3. NMP de bactérias mesófilas totais, em melões rendilhados minimamente processados armazenado a $3^{\circ} \mathrm{C}$ sob atmosfera modificada ativa

\begin{tabular}{ccccc} 
Materiais de & \multicolumn{4}{c}{ Dias de armazenamento } \\
Embalagem & 3 & 6 & 9 & 12 \\
BB-200 & $<0,2 \times 10^{3}$ & $<0,2 \times 10^{3}$ & $0,4 \times 10^{3}$ & $0,4 \times 10^{3}$ \\
PBC & $<0,2 \times 10^{3}$ & $<0,2 \times 10^{3}$ & $1,5 \times 10^{3}$ & $7,4 \times 10^{3}$ \\
PP-10 & $1,2 \times 10^{3}$ & $0,6 \times 10^{3}$ & $5,6 \times 10^{3}$ & $8,3 \times 10^{3}$ \\
Controle & $1,7 \times 10^{3}$ & $12,4 \times 10^{3}$ & $>738 \times 10^{3}$ & $>738 \times 10^{3}$
\end{tabular}

Início: NMP de $3 \times 10^{3} / \mathrm{s}$

Os resultados obtidos representam a média aritmética do NMP (nº mais provável) / $\mathrm{g}$ de produto.

TABELA 4. NMP de coliformes totais, em melões rendilhados minimamente processados armazenado a $3^{\circ} \mathrm{C}$ sob atmosfera modificada ativa

\begin{tabular}{ccccc}
$\begin{array}{c}\text { Materiais de } \\
\text { embalagem }\end{array}$ & 3 & \multicolumn{4}{c}{ Dias de armazenamento } \\
BB-200 & $<0,2 \times 10^{3}$ & $<0,2 \times 10^{3}$ & $<0,2 \times 10^{3}$ & $0,2 \times 10^{3}$ \\
PBC & $<0,2 \times 10^{3}$ & $0,2 \times 10^{3}$ & $0,8 \times 10^{3}$ & $<0,2 \times 10^{3}$ \\
PP-10 & $<0,2 \times 10^{3} 0$ & $<0,2 \times 10^{3}$ & $1,2 \times 10^{3}$ & $<0,2 \times 10^{3}$ \\
Controle & $<0,2 \times 10^{3}$ & $<0,2 \times 10^{3}$ & $2,8 \times 10^{3}$ & $4 \times 10^{3}$
\end{tabular}

Início: NMP de $1,9 \times 10^{3} / \mathrm{g}$ de produto

Os resultados obtidos representam a média aritmética do NMP (no mais provável) / g de produto.

Verifica-se que a partir do 9o dia, a contagem total de bactérias mesófilas ultrapassou $738 \times 10^{3} \mathrm{NMP} / \mathrm{g}$, não sendo possivel determinar o número mais provável, nas amostras controle, pois na maior diluição utilizada, todas as cavidades se mostraram positivas. Nos demais tratamentos os NMP puderam ser determinados e não excederam $8,3 \times 10^{3} \mathrm{NMP} / \mathrm{g}$ de produto. Dessa forma, conclui-se que o uso de atmosfera modificada contribui para a redução da microbiota bacteriana total.

A análise realizada para a contagem total de bactérias mesófilas, visa a detecção das bactérias aeróbias que crescem bem entre 15 e $45^{\circ} \mathrm{C}$, e como as amostras de melão permaneceram armazenadas a $3^{\circ} \mathrm{C}$, provavelmente as contagens efetuadas nesta análise contemplaram também as bactérias psicotróficas, cujo ótimo de temperatura situa-se acima de $20^{\circ} \mathrm{C}$, porém toleram e crescem sob refrigeração. Este fato talvez seja a explicação para o pequeno aumento verificado nas amostras embaladas nos filmes PBC e PP ao longo do armazenamento, onde a modificação da atmosfera reduziu o crescimento de bactérias aeróbias e para o grande aumento nas contagens das amostras controle onde só a temperatura de armazenamento não foi suficiente para inibir o crescimento bacteriano.

BAI, SAFTNER \& WATADA [2] também avaliaram diversos materiais de embalagem para melões Cantaloupe minimamente processados e verificaram que a popula- ção microbiana foi maior nos melões acondicionados em embalagem microperfuradas, onde praticamente não houve modificação da atmosfera.

No presente trabalho os valores iniciais da microbiota bacteriana total encontrados no dia do processamento apresentaram-se superiores aos valores obtidos no $3^{\circ}$ dia de armazenamento, o que comprova a eficácia da operação de sanitização, mesmo durante poucos segundos. BEUCHAT \& BRACKETT [3] citam que a imersão de frutas e hortaliças em água clorada, por, no mínimo, 30 segundos, é suficiente para inativação de microrganismos. A imersão dos pedaços de melões em água clorada foi feita por apenas 3 segundos, em virtude da alta capacidade de absorção de água pelo melão, o que poderia causar mudanças no sabor, caso a imersão fosse por mais tempo. Entretanto, o tempo utilizado mostrou-se eficiente.

Os melões acondicionados na embalagem BB-200 sob atmosfera com alta concentração de $\mathrm{CO}_{2}$ e baixa concentração de $\mathrm{O}_{2}$ apresentaram menores valores de contaminação bacteriana, comprovando o descrito por FARBER [8], que cita o $\mathrm{CO}_{2}$ como principal responsável pelo efeito bacteriostático observado em microrganismos crescendo em ambientes com atmosfera modificada. Segundo o mesmo autor, atmosferas modificadas contendo moderado a alto níveis de $\mathrm{CO}_{2}$ normalmente inibem os microrganismos aeróbios deterioradores; no entanto o crescimento de patógenos pode ocorrer e até ser estimulado.

Pela Tabela 4 é possivel notar que também para as bactérias coliformes, a embalagem BB-200 foi a que apresentou melhor resultado na inibição dessas bactérias. No caso das bactérias coliformes totais a diferença da ação inibidora da embalagem BB-200 não foi tão pronunciada como aquela verificada na análise de bactérias mesófilas totais. Mais uma vez foi possivel observar que nas amostras controle houve aumento da população de bactérias coliformes totais ao longo do armazenamento.

No caso das bactérias coliformes, que são anaeróbias facultativas, a modificação da atmosfera nas embalagens não surtiu tanto efeito como aquele verificado para as bactérias mesófilas totais. Neste caso o efeito da temperatura de armazenamento $\left(3^{\circ} \mathrm{C}\right)$ provavelmente tenha sido o fator principal da inibição bacteriana, uma vez que as bactérias coliformes são mesófilas.

Em nenhuma das amostras de melão analisadas houve detecção de E.coli (Tabela 5), o que as colocam em conformidade com os padrões estabelecidos pela Resolução RDC n ${ }^{\circ} 12$ de 02 de janeiro de 2002 da AGÊNCIA NACIONAL DE VIGILÂNCIA SANITÁRIA [1] do Ministério da Saúde. A referida Resolução estabelece como padrão, o máximo de $5 \times 10^{2} \mathrm{NMP}$ de coliformes fecais por grama de fruta. Embora não existam na legislação padrões para bactérias mesófilas totais e coliformes totais, de forma geral, é preconizado que alimentos contendo contagens microbianas da ordem de $10^{5}-10^{6}$ UFC/g são impróprios para o consumo humano devido à perda do valor nutricional, alterações organolépticas, 
riscos de deterioração e/ou presença de patógenos. No presente trabalho, apenas as amostras de melões acondicionadas em embalagem sem atmosfera modificada apresentaram, a partir do 9 dia de armazenamento, contagens totais de bactérias mesófilas acima de $10^{5}$ $\mathrm{NMP} / \mathrm{g}$, o que poderia torná-las impróprias para o consumo humano, pelos motivos já expostos.

TABELA 5. NMP de E. coli, em melões rendilhados minimamente processados armazenado a $3^{\circ} \mathrm{C}$ sob atmosfera modificada ativa

\begin{tabular}{ccccc} 
Materiais de & \multicolumn{4}{c}{ Dias de armazenamento } \\
embalagem & 3 & 6 & 9 & 12 \\
BB-200 & Ausência & Ausência & Ausência & Ausência \\
PBC & Ausência & Ausência & Ausência & Ausência \\
PP-10 & Ausência & Ausência & Ausência & Ausência \\
Controle & Ausência & Ausência & Ausência & Ausência
\end{tabular}

Início: Ausência / g de produto

\section{3 - Análise sensorial}

Os melões acondicionados em embalagem de polipropileno apresentaram notas de aparência significativamente superiores aos demais tratamentos até o $6^{\circ}$ dia de armazenamento (Tabela 6). Nos demais períodos de armazenamento, não houve diferenças estatísticas entre os tratamentos.

Durante o período de armazenamento, as notas de aparência dos melões acondicionados nesta embalagem permaneceram semelhantes, ou seja, variando de 8 a 7 ("gostei muito" a "gostei regularmente").

Os melões acondicionados em embalagem BB-200 e PBC mantiveram durante todo período de armazenamento notas de aparência semelhantes, variando de 6 a 5 ("gostei ligeiramente" a "não gostei nem desgostei"), enquanto os melões do grupo controle apresentaram notas de aparência entre 7 a 6 ("gostei regularmente" a "gostei ligeiramente").

TABELA 6. Aparência de melões rendilhados minimamente processados armazenado a $3^{\circ} \mathrm{C}$ sob atmosfera modificada $^{1,2)}$

\begin{tabular}{|c|c|c|c|c|}
\hline \multirow{2}{*}{$\begin{array}{l}\text { Materiais de } \\
\text { Embalagem }\end{array}$} & \multicolumn{4}{|c|}{ Dias de armazenamento } \\
\hline & 3 & 6 & 9 & 12 \\
\hline & & ---- Apa & as) ----- & \\
\hline BB-200 & $5,76 \mathrm{c}$ & $6,19 \mathrm{~b}$ & $5,65 \mathrm{a}$ & $5,65 \mathrm{a}$ \\
\hline PBC & $6,00 \mathrm{bc}$ & $5,25 \mathrm{~b}$ & $5,92 \mathrm{a}$ & $5,79 \mathrm{a}$ \\
\hline PP & $8,00 \mathrm{a}$ & $7,82 \mathrm{a}$ & $7,00 \mathrm{a}$ & $7,00 \mathrm{a}$ \\
\hline Controle & $7,20 \mathrm{ab}$ & $6,33 \mathrm{~b}$ & $7,24 \mathrm{a}$ & $6,53 \mathrm{a}$ \\
\hline $\mathrm{CV}(\%)$ & 23,90 & 22,61 & 30,71 & 28,81 \\
\hline
\end{tabular}

${ }^{1)}$ Médias seguidas de mesma letra na coluna não diferem entre si, pelo teste de Tukey ao nivel de $5 \%$ de probabilidade.

${ }^{2}$ Notas: $9=$ gostei extremamente; $8=$ gostei muito; $7=$ gostei moderadamente; $6=$ gostei ligeiramente; $5=$ não gostei nem desgostei; $4=$ desgostei ligeiramente; $3=$ desgostei moderadamente; $2=$ desgostei muito; 1 =desgostei extremamente)

As notas referentes ao aroma variaram de 7 a 6 ("gostei regularmente" a "gostei ligeiramente") nos melões acondicionados em embalagem de polipropileno, BB-200 e PBC (Tabela 7), enquanto as notas dos melões do grupo controle variaram de 7 a 5 ("gostei regularmente"a"não gostei nem desgostei”). Aos 9 dias de armazenamento, os melões do controle apresentaram notas inferiores aos demais tratamentos, diferindo estatisticamente dos melões acondicionados em embalagem BB-200.

TABELA 7. Aroma de melões rendilhados minimamente processados armazenado a $3^{\circ} \mathrm{C}$ sob atmosfera modificada ${ }^{(1,2)}$

\begin{tabular}{ccccc} 
Materiais de & \multicolumn{4}{c}{ Dias de armazenamento } \\
Embalagem & 3 & \multicolumn{4}{c}{6} & 9 \\
& & --- Aroma (Notas) & 12 \\
BB-200 & 7,00 a & 7,29 a & 7,03 a & 6,65 a \\
PBC & 6,60 a & $6,53 \mathrm{a}$ & $6,65 \mathrm{ab}$ & $6,00 \mathrm{a}$ \\
PP & $7,13 \mathrm{a}$ & $7,00 \mathrm{a}$ & $6,71 \mathrm{ab}$ & $7,00 \mathrm{a}$ \\
Controle & $7,35 \mathrm{a}$ & $6,53 \mathrm{a}$ & $5,31 \mathrm{~b}$ & - \\
CV $(\%)$ & 19,61 & 22,98 & 26,90 & 43,98
\end{tabular}

1) Médias seguidas de mesma letra na coluna não diferem entre si, pelo teste de Tukey ao nivel de $5 \%$ de probabilidade.

${ }^{2)}$ Notas: $9=$ gostei extremamente; $8=$ gostei muito; 7 =gostei moderadamente; $6=$ gostei ligeiramente; $5=$ não gostei nem desgostei; $4=$ desgostei ligeiramente; $3=$ desgostei moderadamente; $2=$ desgostei muito; $1=$ desgostei extremamente)

Não foram observadas diferenças estatísticas entre os tratamentos para as notas de sabor em nenhum dos períodos de armazenamento, embora o sabor dos melões acondicionados nas embalagens BB e PP mantiveram acima do limite de aceitabilidade durante todo período de armazenamento, enquanto os melões do controle apresentaram no 9o dia de armazenamento nota inferior a 5 (limite de aceitabilidade), sendo considerado com sabor de fermentado por alguns provadores. Os melões acondicionados em embalagem PBC também apresentaram alteração do sabor no $12^{\circ}$ dia (Tabela 8 ).

TABELA 8. Sabor de melões rendilhados minimamente processados armazenado a $3^{\circ} \mathrm{C}$ sob atmosfera modificada ativa $^{(1,2)}$

\begin{tabular}{|c|c|c|c|c|}
\hline \multirow{2}{*}{$\begin{array}{l}\text { Materiais de } \\
\text { Embalagem }\end{array}$} & \multicolumn{4}{|c|}{ Dias de armazenamento } \\
\hline & 3 & 6 & 9 & 12 \\
\hline & & $-\mathrm{sa}^{2}$ & & \\
\hline $\mathrm{PBC}$ & 587 & 520. & 506 & 4 \\
\hline & 75 & - & 500 & $5,2+a$ \\
\hline Controle & 6,65 a & 6,41 a & $4,88 \mathrm{a}$ & \\
\hline $\mathrm{CV}(\%)$ & 30,94 & 35,35 & 43,37 & 45,05 \\
\hline
\end{tabular}

1) Médias seguidas de mesma letra na coluna não diferem entre si, pelo teste de Tukey ao nivel de $5 \%$ de probabilidade.

${ }^{2)}$ Notas: 9=gostei extremamente; $8=$ gostei muito; 7 =gostei moderadamente; $6=$ gostei ligeiramente; $5=$ não gostei nem desgostei; $4=$ desgostei ligeiramente; $3=$ desgostei moderadamente; $2=$ desgostei muito; $1=$ desgostei extremamente)

\section{4 - Análise físico-química}

A Tabela 9 indica os valores de coloração expressos em Luminosidade(L), sendo que os menores valores de $\mathrm{L}$ representam maior escurecimento da polpa de melão, na região placentária.

Observa-se que a embalagem PP propiciou valores significativamente maiores de L em relação às embalagens BB-200 e PBC em todo período de armazenamento e em relação ao controle no $6^{\circ}$ e $9^{\circ}$ dia de armazenamento. Estes resultados refletiram na boa aparência do produto, onde os melões acondicionados na emba- 
lagem PP apresentaram notas de aparência superior a 7, correspondente ao termo 'gostei moderadamente' (Tabela 6) durante todo período de armazenamento.

TABELA 9. Escurecimento da polpa de melões rendilhados minimamente processados armazenado a $3^{\circ} \mathrm{C}$ sob atmosfera modificada ativa

\begin{tabular}{ccccc} 
Materiais de & \multicolumn{4}{c}{ Dias de armazenamento } \\
Embalagem & 3 & 6 & 9 & 12 \\
& - & $54,08 \mathrm{~b}$ & $56,03 \mathrm{~b}$ & $50,42 \mathrm{~b}$ \\
BB-200 & $52,51 \mathrm{~b}$ & $55,53 \mathrm{~b}$ & $55,86 \mathrm{~b}$ & $49,08 \mathrm{~b}$ \\
PBC & $52,71 \mathrm{~b}$ & $63,95 \mathrm{a}$ & $63,51 \mathrm{a}$ & $61,50 \mathrm{a}$ \\
PP & $61,71 \mathrm{a}$ & $56,26 \mathrm{~b}$ & $57,11 \mathrm{~b}$ & $58,50 \mathrm{ab}$ \\
Controle & $56,06 \mathrm{ab}$ & 4,57 & 4,04 & 8,60 \\
CV $(\%)$ & 5,74 & &
\end{tabular}

Valor inicial: 64,81

Não houve efeito da alteração da composição gasosa sobre a firmeza, sólidos solúveis totais, $\mathrm{pH}$, acidez titulável e ácido ascórbico dos melões. A Tabela 10 apresenta os valores médios destas variáveis.

TABELA 10. Valores médios de firmeza, sólidos solúveis totais, pH, acidez titulável e ácido ascórbico da polpa de melões rendilhados minimamente processados armazenado a $3^{\circ} \mathrm{C}$ sob atmosfera modificada ativa

\begin{tabular}{lcccc}
\hline \multicolumn{1}{c}{ Variáveis } & \multicolumn{4}{c}{ Materiais de embalagem } \\
& BB-200 & PBC & PP & Controle \\
\hline Firmeza (N) & 2,15 & 2,07 & 2,50 & 2,48 \\
$\begin{array}{l}\text { Sólidos Solúveis } \\
\text { Totais ( }{ }^{\circ} \text { Brix) }\end{array}$ & 7,37 & 7,38 & 7,36 & 8,58 \\
PH & 5,78 & 5,80 & 5,76 & 5,82 \\
$\begin{array}{l}\text { Acidez titulável } \\
\text { (\% de ácido málico) }\end{array}$ & 0,09 & 0,08 & 0,08 & 0,08 \\
$\begin{array}{l}\text { Ácido ascó rbico } \\
\text { (mg/100g polpa) }\end{array}$ & 1,93 & 1,84 & 1,91 & 1,86 \\
\hline
\end{tabular}

Com relação às características físico-químicas observou-se efeito da composição gasosa apenas na coloração da polpa. De modo similar, as características sensoriais foram pouco afetadas pelos tratamentos. Em relação às características microbiológicas, apenas os melões controle apresentaram contagem total de bactérias mesófilas acima de $10^{5} \mathrm{NMP} / \mathrm{g}$, com riscos de deterioração e/ou presença de patógenos. Não foram detectados Escherichia coli em nenhum dos tratamentos, demonstrando a eficácia dos cuidados higiênico-sanitários realizados durante as etapas do processamento.

\section{4 - CONCLUSÕES}

- Melões rendilhados minimamente processados armazenados a $3^{\circ} \mathrm{C}$ sem atmosfera modificada foram conservados por 6 dias.

- Melões rendilhados minimamente processados acondicionados em embalagem $\mathrm{PBC}$ com $5 \% \mathrm{O}_{2}+20 \% \mathrm{CO}_{2}+$
$75 \% \mathrm{~N}_{2}$ e armazenados a $3^{\circ} \mathrm{C}$ foram conservados por 9 dias.

- Melões rendilhados minimamente processados acondicionados em embalagem BB-200 ou PP com $5 \% \mathrm{O}_{2}+20 \% \mathrm{CO}_{2}+75 \% \mathrm{~N}_{2}$ e armazenados a $3{ }^{\circ} \mathrm{C}$ foram conservados por 12 dias.

- A atmosfera modificada ativa mostrou-se eficiente no controle de microrganismos em melões rendilhados minimamente processados, armazenados a $3^{\circ} \mathrm{C}$.

\section{5 - REFERÊNCIAS BIBLIOGRÁFICAS}

[1] AGÊNCIA NACIONAL DE VIGILÂNCIA SANITÁRIA. Resolução - RDC $n^{\circ} 12$, de 2 de janeiro de 2001. www.anvisa.gov.br/legis/resol/12_01rdc.htm (21 fev. 2002).

[2] BAI, J.H.; SAFTNER, R.A.; WATADA, A.E. et al. Modified atmosphere maintains quality of fresh cut Cantaloupe (Cucumis melo L.). Journal of Food Science, v. 66, n. 8, p. 1207-1211, 2001.

[3] BEUCHAT, L.R.; BRACKETT, R.E. Survival and growth of Listeria monocytogenes on lettuce as influenced by shredding, chlorine treatment, modified atmosphere packaging and temperature. Journal of Food Science, n. 55, p. 755-758, 1990.

[4] BOLIN, H.R.; HUXSOLL, C.C. Storage stability of minimally processed fruit. Journal of Food Processing and Preservation, v. 13, p. 281-292, 1989.

[5] BRECHT, J.K. Physiology of lightly processed fruits and vegetables. HortScience, v. 30, n. 1, p. 18-22, 1995.

[6] BURNS, J.K. Lightly processed fruits and vegetables: Introduction to the Colloquium. HortScience, v. 30, n. 1, p. 14-17, 1995.

[7] CARVALHO, C.R.L.; MANTOVANI, D.M.B.; CARVALHO, P.R.N. Análises químicas em alimentos. Campinas: ITAL, 1990.121p. (Manual Técnico).

[8] FARBER, J.M. Microbiological aspects of modified atmosphere packaging technology - a review. Journal of Food Protection. v. 54, n. 1, p. 58-70, 1991.

[9] KADER, A.A. Biochemical and physiological basics for effects of controlled and modified atmospheres on fruits and vegetable. Food Technology, v. 40, n. 5, p. 99$104,1986$.

[10] MATHOOKO, F.M. Regulation of ethylene biosynthesis in higher plants by carbon dioxide. Postharvest Biology and Technology, v. 7, p. 1-26, 1996.

[11] OLIVEIRA, L.M.; ALVES, R.M.V.; SARANTÓPOULOS, C.I.G.L. Ensaios para avaliação de embalagens plásticas flexíveis. Campinas:ITAL, CETEA, 1996.219p.

[12] PERYAM, D.R.; GIRARDOT, N.F. Advanced taste method. Food Engeneiring, v. 24, p. 58-61, 1952.

[13] SHEWFELT, R.L. Postharvest treatment for extending the shelf life of fruits and vegetables. Food Technology, n. 5, p. 70-80, 1987.

[14] WILEY, R.C. Minimally processed refrigerated fruits and vegetables. New York: Chapman \& Hall, 1994. 368p.

\section{6 - AGRADECIMENTOS}

Os autores agradecem à FAPESP pelo apoio financeiro concedido. 